\title{
Genotyping Male-Specific RNA Coliphages by Hybridization with Oligonucleotide Probes
}

\author{
FU-CHIH HSU, ${ }^{1}$ Y.-S. CAROL SHIEH, ${ }^{1}$ J. VAN DUIN, ${ }^{2}$ M. J. BEEKWILDER, ${ }^{2}$ \\ AND MARK D. SOBSEY ${ }^{1 *}$ \\ University of North Carolina, Chapel Hill, North Carolina $27599,{ }^{1}$ and \\ Leiden University, Leiden, The Netherlands ${ }^{2}$
}

Received 6 March 1995/Accepted 21 August 1995

\begin{abstract}
F-specific $\left(\mathrm{F}^{+}\right)$RNA coliphages are prevalent in sewage and other fecal wastes of humans and animals. There are four antigenically distinct serogroups of $\mathrm{F}^{+}$RNA coliphages, and those predominating in humans (groups II and III) differ from those predominating in animals (groups I and IV). Hence, it may be possible to distinguish between human and animal wastes by serotyping $\mathrm{F}^{+}$RNA coliphage isolates. Because serotyping is laborious and requires scarce antiserum reagents, we investigated genotyping using synthetic oligonucleotide probes as an alternative approach to distinguishing the four groups of $\mathrm{F}^{+}$RNA coliphages. Oligoprobes I, II, III, IV, A, and B were selected to detect group I, II, III, IV, I plus II, and III plus IV phages, respectively. Methods for phage transfer from zones of lysis on a host cell lawn to candidate membrane filters and fixation of genomic nucleic acid on the membranes were optimized. The oligoprobes, which were end labeled with digoxigenin, were applied in DNA-RNA hybridizations, and hybrids were observed by colorimetric, immunoenzymatic detection. Of 203 isolates of $\mathrm{F}^{+}$RNA coliphages from environmental samples of water, wastes, and shellfish, 99.5 and $96.6 \%$ could be classified into each group by serotyping and genotyping, respectively. Probes $A$ and $B$ correctly identified $100 \%$ of the isolates. On the basis of these results, this method for genotyping $\mathrm{F}^{+}$ RNA coliphages appears to be practical and reliable for typing isolates in field samples.
\end{abstract}

Water and food contaminated by feces may contain a great variety of gastrointestinal (enteric) viruses, which are major agents of food-borne and waterborne outbreaks of diseases such as gastroenteritis and infectious hepatitis $(19,26)$. While monitoring of the virological quality of water and food would be useful, it is impractical because of technical complexities, lengthy analytical time, and high cost. Furthermore, some epidemiologically important enteric viruses are unculturable (Norwalk virus) or inefficiently cultured (hepatitis A virus). Even the newer nucleic acid amplification and detection methods, such as PCR and reverse transcription-PCR, are still too complex, technically demanding, and costly for the routine monitoring of human viral pathogens in environmental samples. For this reason, there is a need to find reliable, rapid, and economical indicators for detecting fecal contamination by enteric viruses and other pathogens in water, shellfish, and other food.

Because no consistent and reliable relationships between fecal indicator bacteria and enteric viruses have been demonstrated (24), enteric bacteriophages have been recommended for the role of enteric virus indicators $(13,18)$. F-specific $\left(\mathrm{F}^{+}\right)$ RNA coliphages may be good indicators for monitoring the virological quality of water and food because they superficially resemble enteroviruses, caliciviruses, and hepatitis A virus. They also are consistently present in a variety of wastewaters, and they are sufficiently persistent in the environment (15-17) and resistant to treatment processes to be acceptable enteric virus indicators. A prototype $\mathrm{F}^{+}$RNA coliphage, MS2, has been shown to be very persistent in water and shellfish and more resistant to disinfection by such agents as UV irradiation and monochloramine than other organisms, including hepatitis

\footnotetext{
* Corresponding author. Mailing address: University of North Carolina, CB \#7400, Rosenau Hall, Room 106, Chapel Hill, NC 275997400. Phone: (919) 966-7303. Fax: (919) 966-4711. Electronic mail address (Internet): Sobsey@SOPHIA.SPH.UNC.EDU.
}

A virus, coxsackievirus B5, Escherichia coli, and Klebsiella pneumoniae $(4,6)$. Overall, these properties make MS2 and similar $\mathrm{F}^{+}$RNA coliphages desirable candidates for human enteric virus indicators (15).

$\mathrm{F}^{+}$RNA coliphages are composed of serogroups I through IV. Strains isolated from human feces are usually groups II and III, while groups I and IV are usually found in animal feces (12, 27). The risk of viral gastroenteritis and hepatitis in humans resulting from ingestion of fecally contaminated water and food is considered higher for human feces than for animal feces, because enteric viruses from animal sources are not significant causes of human illness (22). Hence, determining if fecal contamination is human or animal in origin may aid in establishing its risk. Serotyping of $\mathrm{F}^{+}$RNA coliphages may distinguish human fecal contamination from animal fecal contamination. However, antisera for the $\mathrm{F}^{+}$RNA coliphages are not readily available and some isolates are difficult to serotype. Several isolates have been found to be neutralized by two heterologous antisera (7, 9-12). Genotyping by nucleic acid hybridization methods may be a reliable, rapid, simple, and inexpensive alternative to serotyping. Hence, in this study, we developed a genotyping method to group $\mathrm{F}^{+}$RNA coliphages by nucleic acid hybridization with nonradioactive oligonucleotide probes and compared this method with serotyping.

\section{MATERIALS AND METHODS}

$\mathrm{F}^{+}$RNA coliphages and host cells. Five representative $\mathrm{F}^{+}$RNA coliphage strains, MS2 (group I), GA (group II), Q $\beta$ (group III), and FI and SP (group IV), were kindly provided by K. Furuse (Tokai University, Bohseidai, Iseharashi, Japan). The host was a genetically constructed strain of Salmonella typhimurium, WG49, containing the E. coli plasmid (F'42 lac::Tn5) that encodes pilus production (17). This host strain, which is insensitive to somatic coliphages but highly sensitive to $\mathrm{F}^{+}$RNA coliphages, was grown in tryptone-yeast extract-glucose broth containing $1.3 \%$ tryptone, $0.1 \%$ yeast extract, $0.8 \% \mathrm{NaCl}, 0.1 \%$ glucose, $0.03 \% \mathrm{CaCl}_{2} \cdot 2 \mathrm{H}_{2} \mathrm{O}, 100 \mathrm{mg}$ of nalidixic acid per liter, and $20 \mathrm{mg}$ of kanamycin sulfate per liter. Broth cultures in baffled shaker flasks of medium were inoculated with host cells from frozen stock and grown with shaking at $37^{\circ} \mathrm{C}$ overnight. Preparation of environmental samples. The environmental samples included 
TABLE 1. Nucleotide sequences of oligomers used for probing of $\mathrm{F}^{+}$RNA coliphages

\begin{tabular}{|c|c|c|c|c|c|}
\hline Probe & Sequence $^{a}$ & Locus & $\begin{array}{l}\text { Length } \\
\text { (bases) }\end{array}$ & $\begin{array}{c}T_{m} \\
\left({ }^{\circ} \mathrm{C}\right)^{b}\end{array}$ & $\begin{array}{l}\text { Source phage(s) } \\
\text { (group) }\end{array}$ \\
\hline I & CTAAGGTATGGACCATCGAGAAAGGA & Maturation protein & 26 & 66.9 & MS2 (I) \\
\hline II & CCATGTTATCCCCCAAGTTGCTGGCTAT & Maturation protein & 27 & 73.7 & GA (II) \\
\hline III & ATACTCAGTGAA(A/G)TACTGCTGTGT & $5^{\prime}$ end nontranslated region & 25 & 58.6 & $\mathrm{Q} \beta$ (III) \\
\hline IV & GGCATAGATTCTCCTCTGTAGTGCG & $5^{\prime}$ end nontranslated region ${ }^{c}$ & 25 & 66.3 & SP (IV) \\
\hline A & AGCCCGATCTATTTTATTGTTCTTCGGAAC & Replicase & 30 & 72.1 & MS2 and GA \\
\hline B & TAATTTTGCCATGATCGAATTGACCCAAAC & Nontranslated region and coat protein ${ }^{d}$ & 30 & 74.4 & $\mathrm{Q} \beta$ and $\mathrm{SP}$ \\
\hline
\end{tabular}

${ }^{a}$ The probe I sequence extends from nucleotide 1248 to 1273 in phage MS2, the probe II sequence extends from nucleotide 431 to 457 in phage GA, the probe III sequence extends from nucleotide 27 to 51 in phage $\mathrm{Q} \beta$, the probe IV sequence extends from nucleotide 35 to 59 in phage SP, the probe A sequence extends from nucleotide 2340 to 2369 in phage MS2 and from nucleotide 2345 to 2375 in phage GA, and the probe B sequence extends from nucleotide 1327 to 1356 in phage Q $\beta$ and from nucleotide 1409 to 1438 in phage SP.

${ }^{b}$ The formula $T_{m}=\Delta H /\left(\Delta S+R \ln C_{\mathrm{T}}\right)-273.15$, where $H$ is the enthalpy, $S$ is the entropy, $R$ is 1.987 cal $(8.314 \mathrm{~J}) \mathrm{K}^{-1} \mathrm{~mol}^{-1}$, and $C_{T}$ is the total concentration, was used to calculate $T_{m}$ with the computer program Gene Runner (Hastings Software, Inc.).

${ }^{c}$ Five nucleotides are located in the maturation protein region.

${ }^{d}$ Twelve nucleotides are located in the coat protein region in phage $\mathrm{Q} \beta$ and 11 nucleotides are located in the coat protein region in phage SP.

sewage, animal feces, oysters, and seawater. Sewage samples were supplemented with one-third of a volume of trichlorotrifluoroethane (Freon), vortexed vigorously for $2 \mathrm{~min}$, and centrifuged at $5,000 \times g$ for $20 \mathrm{~min}$ at $5^{\circ} \mathrm{C}$. The supernatant was concentrated 30 -fold by centrifugal ultrafiltration at $900 \times g$ using YM100 membranes (Amicon, Danvers, Mass.). Fecal samples were diluted 10-fold in phosphate-buffered saline (PBS) containing $0.2 \%$ Tween 80 and $15 \%$ glycerol, vortexed rapidly, and centrifuged at $5,000 \times g$ for 20 min to remove solids. $\mathrm{F}^{+}$ RNA coliphages were extracted from oysters by homogenizing in an Omni-mixer (Sorvall, Newton, Conn.) with an equal amount (wt/vol) of nutrient broth containing $0.5 \%$ Tween 80 and then centrifuging the mixture at $5,500 \times g$ for $20 \mathrm{~min}$ to sediment unwanted solids (7).

Infectivity assay of $\mathrm{F}^{+}$RNA coliphages in environmental samples. $\mathrm{F}^{+}$RNA coliphages present in feces, sewage, and oyster extract samples were detected by the double agar layer plaque assay technique (2). $\mathrm{F}^{+}$RNA coliphages in water samples were concentrated and quantified by a previously described direct membrane filtration method (31).

Isolation of $\mathrm{F}^{+}$RNA coliphages from environmental samples. $\mathrm{F}^{+}$RNA coliphages were isolated from individual plaques of assay plates with fewer than 50 PFU by aspirating the plaques with a micropipette and suspending the coliphages in $0.5 \mathrm{ml}$ of PBS containing $15 \%$ glycerol. Isolates were tested with RNase A (type I-A; Sigma, St. Louis, Mo.) to distinguish between RNA and DNA phages. This was done by spotting $5-\mu l$ suspensions of isolates on premade lawns of WG49 host cells in tryptone-yeast extract-glucose agar containing $100 \mu \mathrm{g}$ of RNase per ml.

Serotyping of $\mathbf{F}^{+}$RNA coliphages. Isolates were rapidly serotyped by a spot test (34). Twenty-microliter volumes of undiluted and 10- and 100-fold-diluted isolate were spotted on premade lawns of WG49 host cells in tryptone-yeast extract-glucose agar containing one of five $\mathrm{F}^{+}$RNA coliphage-neutralizing antisera $[\alpha \mathrm{MS} 2(\mathrm{I}), \alpha \mathrm{GA}(\mathrm{II}), \alpha \mathrm{Q} \beta(\mathrm{III}), \alpha \mathrm{FI}(\mathrm{IVa})$, and $\alpha \mathrm{SP}(\mathrm{IV}])$. Each antiserum was used at a dilution that achieved about three $\log _{10}$ reductions of the previously listed prototype phage of the same serogroup, and these phages were included as positive controls. After overnight incubation at $37^{\circ} \mathrm{C}$, serotypes were determined by scoring coliphage plates exhibiting the presence or absence of clear zones of lysis on the lawns. The absence of a lysis zone on a lawn was considered complete neutralization of phage infectivity by the antiserum in that plate and positive identification of the phage serotype if the same isolate was not neutralized by any other antisera (lysis present).

Phage transfer and fixation for hybridization. The method for phage transfer and fixation onto membranes was modified from that of Benton and Davis (5). In brief, $2-\mu \mathrm{l}$ volumes of environmental isolates and the five prototype strains representative of each group were spotted on lawns of host WG49 and incubated at $37^{\circ} \mathrm{C}$ overnight. Plates were incubated at $4^{\circ} \mathrm{C}$ for $30 \mathrm{~min}$ and then were covered with nylon membranes to adsorb phages from zones of lysis for $2 \mathrm{~min}$ ( $4 \mathrm{~min}$ for the second transfer). The adsorption efficiencies of the following five nylon membrane filters, $0.45-\mu \mathrm{m}$ pore size, were compared: GeneScreen (NEN Research Products, Boston, Mass.), nylon membranes (Boehringer Mannheim Corporation, Indianapolis, Ind.), Biotrans (ICN Radiochemicals, Inc., Irvine, Calif.), Biodyne (PALL Biosupport, East Hills, N.Y.), and Zeta-probe blotting membranes (Bio-Rad Laboratories, Richmond, Calif.).

The following three solutions were compared for the efficiency of denaturation: (i) $0.05 \mathrm{~N} \mathrm{NaOH}$ (1 min of fixation and $1 \mathrm{~min}$ of neutralization by $0.1 \mathrm{M}$ sodium acetate, $\mathrm{pH} 6.0$ ), (ii) $37 \%$ formaldehyde for $2 \mathrm{~min}$, and (iii) blotting buffer plus $65^{\circ} \mathrm{C}$ heat treatment for $15 \mathrm{~min}$; blotting buffer contained $7.5 \times \mathrm{SSC}$ $(20 \times \mathrm{SSC}$ is $3 \mathrm{M} \mathrm{NaCl}$ plus $0.3 \mathrm{M}$ sodium citrate, $\mathrm{pH} 7.0)$ and $4.6 \mathrm{M}$ formaldehyde. The membranes were then treated to cross-link the denatured nucleic acid by irradiation with UV light for $5 \mathrm{~min}$ and baking at $80^{\circ} \mathrm{C}$ for $15 \mathrm{~min}$ in a vacuum oven prior to hybridization.

Nonradioactive oligonucleotide probe selection and labeling. The six oligonucleotides ultimately used as genotype probes are summarized in Table 1. Initially, six oligonucleotide probes (I, II, III, IV, A, and B) developed by two of us (J. van Duin and M. J. Beekwilder) were tested. Despite systematic and repeated attempts to optimize hybridization conditions for all of these probes, probes I and II were found to produce considerable cross-reactivity with group IV phages (FI and SP) at $50^{\circ} \mathrm{C}$. Therefore, oligonucleotide sequences for alternate probes I and II having less sequence homology with phages of heterologous groups were selected. This was done by performing a multiple nucleotide sequence alignment analysis on phages MS2, GA, QB, and SP using a nucleic acid sequence alignment and analysis software program (MACAW; National Center for Biotechnology Information, Bethesda, Md.). These oligonucleotides were analyzed for melting temperature $\left(T_{m}\right)$, percent GC content, and most stable hairpin loops and dimers with the computer program Gene Runner (Hastings Software, Inc., Hastings, N.Y.). The other four probes (III, IV, A, and B) gave acceptable hybridization results with prototype phages. Oligonucleotides were labeled at the $3^{\prime}$ end with digoxigenin (DIG)-dUTP by terminal transferase by using the Genius 5 Oligonucleotide 3'-End Labeling Kit (Boehringer Mannheim Corporation). After the labeling reaction was completed, ethanol precipitation was performed to remove unincorporated DIG-dUTP from the labeled oligonucleotides, and probes were stored at $-20^{\circ} \mathrm{C}$ until use.

Hybridization conditions and hybrid detection. Fixed membranes were prehybridized for $2 \mathrm{~h}$ at $45^{\circ} \mathrm{C}$ in prehybridization solution containing $6 \times \mathrm{SSC}, 5 \times$ Denhardt's solution, $16 \mathrm{mM}$ Tris- $\mathrm{HCl}$ buffer $(\mathrm{pH} 8.3), 0.1 \%$ sodium dodecyl sulfate (SDS), and $75 \mu \mathrm{g}$ of salmon sperm DNA per ml. Hybridization was performed in the same solution by adding 5 pmol of DIG-dUTP-labeled probe overnight at $45^{\circ} \mathrm{C}$. After hybridization, the membranes were washed twice in $6 \times$ SSC $-0.01 \%$ SDS at $40^{\circ} \mathrm{C}$ for $15 \mathrm{~min}$. Membranes were incubated with an alkaline phosphatase-conjugated anti-DIG antibody at room temperature for $30 \mathrm{~min}$. The unbound antibody conjugate was removed by washing membranes with a solution containing $100 \mathrm{mM}$ Tris- $\mathrm{HCl}$ and $150 \mathrm{mM} \mathrm{NaCl}(\mathrm{pH} 7)$

Colorimetric detection was performed by using the substrates 5-bromo-4chloro-3-indolylphosphate and nitroblue tetrazolium chloride (Boehringer Mannheim) to visualize DNA-RNA hybrids. Hybrids appeared as dark-blue circular spots on the membranes within 8 to $12 \mathrm{~h}$ of incubation.

Data analysis. Classification results for 203 field isolates of $\mathrm{F}^{+}$RNA coliphages grouped by serotyping and genotyping were compared by two-way analysis of variance performed with SAS software (SAS Institute, Inc., Cary, N.C.) The $P$ value was calculated to test for a statistically significant difference between serotyping and genotyping at the $5 \%$ level.

\section{RESULTS}

Efficiency of plaque transfer and fixation by three denaturing solutions. An alkaline solution of $0.5 \mathrm{~N} \mathrm{NaOH}$ has often been used to denature DNA and fix it on membranes for plaque hybridization (5). However, to prevent RNA from being hydrolyzed, a $0.05 \mathrm{~N} \mathrm{NaOH}$ solution was tested in this study. The other two denaturing solutions tested were mainly constituted of formaldehyde (see Materials and Methods). As shown in Fig. 1, oligoprobes I and II were highly specific for detecting the RNA of their target prototype phages (MS2 and GA, respectively) as circular lysis zones. Of the three denaturing solutions, the blotting buffer $(7.5 \times \mathrm{SSC}$ with $4.6 \mathrm{M}$ formaldehyde) plus heating gave the highest efficiency of denaturation for oligoprobe detection. The hybridization signal intensity of the MS2 and GA lysis zones was weak when either 

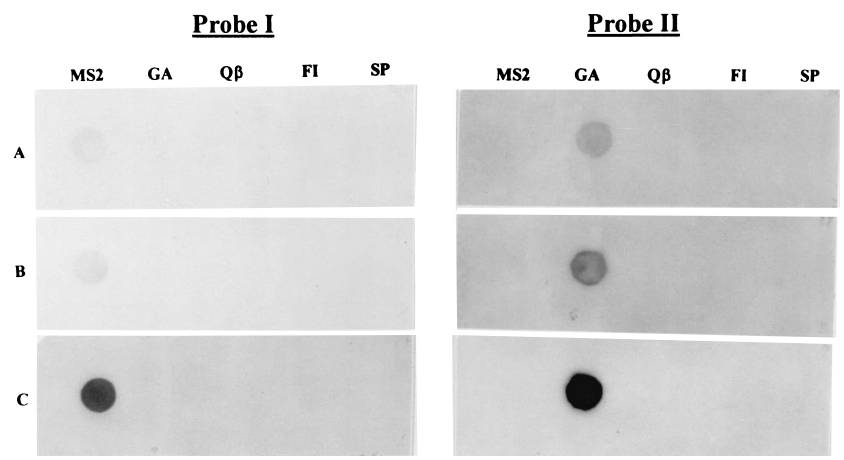

FIG. 1. Lysis zone (plaque) hybridization of $\mathrm{F}^{+}$RNA coliphages fixed by three denaturing methods. (Row A) Membranes fixed in $0.05 \mathrm{~N} \mathrm{NaOH}$ for 1 min and neutralized with $0.1 \mathrm{M}$ sodium acetate for $1 \mathrm{~min}$; (row B) membranes fixed with $37 \%$ formaldehyde for $2 \mathrm{~min}$; (row C) membranes fixed with blotting buffer (7.5 $\times$ SSC plus $4.6 \mathrm{M}$ formaldehyde) for $15 \mathrm{~min}$ at $65^{\circ} \mathrm{C}$.

$0.05 \mathrm{~N} \mathrm{NaOH}$ or $37 \%$ formaldehyde was used to fix phage RNA on membranes. The blotting buffer with heating also gave the strongest signal for phages $\mathrm{Q} \beta$ (group III) and FI and SP (group IV) after hybridization (data not shown).

Efficiencies of phage transfer with five filters. Five commercially available membranes were examined for their efficiencies of phage transfer from circular lysis zones on host lawns in conjunction with the use of the blotting buffer at $65^{\circ} \mathrm{C}$ to denature $\mathrm{F}^{+}$RNA coliphages. The results of an experiment in which the five filters were tested with the five prototype phages by using probes against group I and group II phages are summarized in Fig. 2. Membranes A and B showed a nonspecific hybridization reaction, in which a heterologous phage of group II (GA) was moderately recognized by probe I. Membranes C, $\mathrm{D}$, and $\mathrm{E}$ gave specific and similar efficiencies of phage transfer and detection of prototype group I phage MS2 by probe I. All five filters also gave specific and similar efficiencies of transfer and detection of prototype group II phage GA by hybridization with probe II (Fig. 2). Weak hybridization signals also were observed when membranes $\mathrm{A}$ and $\mathrm{B}$ were used to transfer and

Probe I

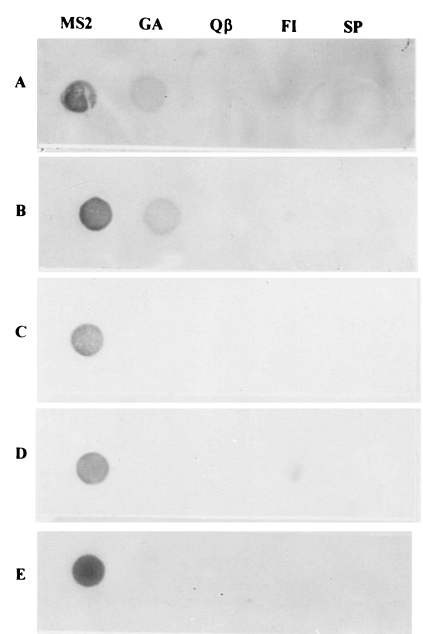

FIG. 2. Lysis zone (plaque) hybridization of five $\mathrm{F}^{+}$RNA coliphages on five filters tested with probes I and II. Results for Zeta-probe (A), Biotrans (B), Biodyne (C), Boehringer Mannheim nylon membrane (D), and GeneScreen (E) are shown.

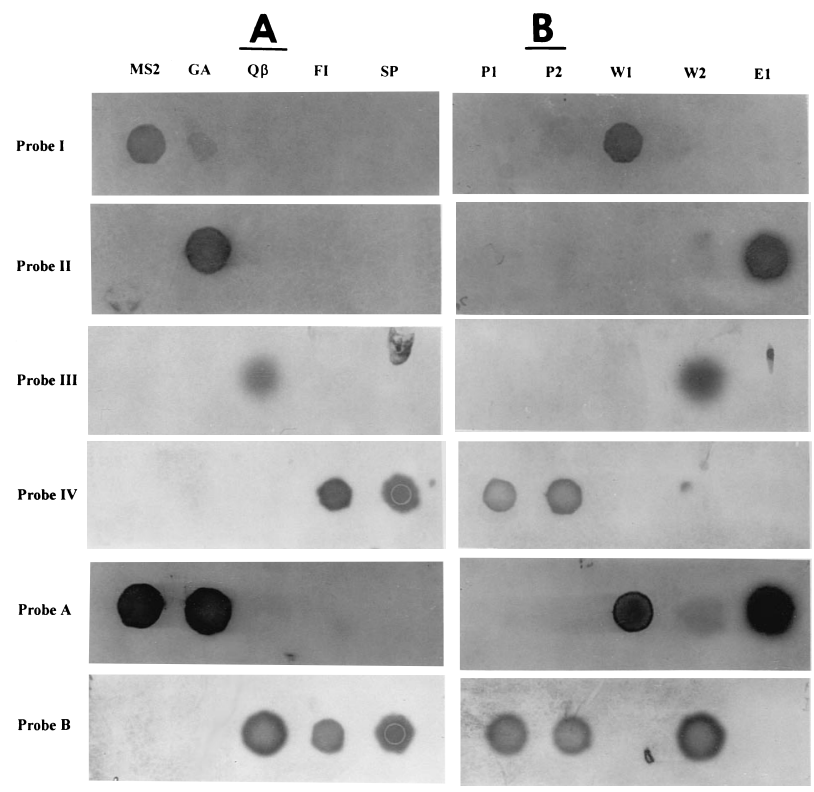

FIG. 3. Lysis zone (plaque) hybridization for determining the specificities of six probes and for classifying five isolates from environmental samples. Column A contains five prototype $\mathrm{F}^{+}$RNA coliphages, and column B contains isolates $\mathrm{P} 1$ and $\mathrm{P} 2$ from piglet feces, W1 and W2 from surface water, and E1 from secondary effluent. Pairs of membranes in each row were hybridized with probes I, II, III, $\mathrm{IV}, \mathrm{A}$, and $\mathrm{B}$, respectively.

fix Q $\beta$ (group III), FI (group IV), and SP (group IV) phages after they were hybridized with probes III and IV, respectively (data not shown). However, filters $\mathrm{C}, \mathrm{D}$, and $\mathrm{E}$ gave similar specific reactions of phages $\mathrm{Q} \beta$, FI, and SP with their respective probes. It appears that membranes $\mathrm{C}, \mathrm{D}$, and $\mathrm{E}$ are capable of transferring an amount of $\mathrm{F}^{+}$RNA coliphages sufficient to perform reliable and specific hybridization with each probe.

Hybridization conditions. A hybridization solution containing $5 \times \mathrm{SSC}, 0.1 \% \mathrm{~N}$-lauroylsarcosine, $0.02 \% \mathrm{SDS}$, and $1.0 \%$ (wt/vol) blocking reagent (recommended by The User's Guide for Filter Hybridization [6a]) yielded poor sensitivity in this study (data not shown). After colorimetric detection, the strength of the signal from hybridized lysis zones was weak. However, this problem was solved by using a different hybridization solution $(6 \times$ SSC, $16 \mathrm{mM}$ Tris- $\mathrm{HCl}, 0.1 \%$ SDS, $75 \mu \mathrm{g}$ of salmon sperm DNA per $\mathrm{ml}$ ) with $5 \times$ Denhardt's solution ( $0.1 \%$ Ficoll, $0.1 \%$ bovine serum albumin fraction $\mathrm{V}, 0.1 \%$ polyvinylpyrrolidone), as shown by the hybridization results presented in Fig. 1 and 2.

Hybridization is usually performed at 5 to $10^{\circ} \mathrm{C}$ below $T_{m}$ (28). The $T_{m}$ s of our oligonucleotides ranged from 58 to $74^{\circ} \mathrm{C}$ (Table 1). When the hybridization reaction was carried out at 50 and $55^{\circ} \mathrm{C}$, a high background was observed, although there was no nonspecific hybridization between the probes and targets (data not shown). When two lower temperatures, 37 and $45^{\circ} \mathrm{C}$, were tested in order to overcome this problem, there was little background, but at $37^{\circ} \mathrm{C}$, nonspecific binding occasionally occurred during a long period of color development. Therefore, the hybridization temperature was set at $45^{\circ} \mathrm{C}$.

Specificities of probes. Five prototype $\mathrm{F}^{+}$RNA coliphages and five serotyped isolates from field samples (P1 and P2 from piglet feces, W1 and W2 from surface water, and E1 from secondary effluent) were used simultaneously to test the specificity of each probe. All six probes hybridized only with their specific prototype strain and field isolate group members (as determined serologically), and no cross-reactions with heter- 
Probe I
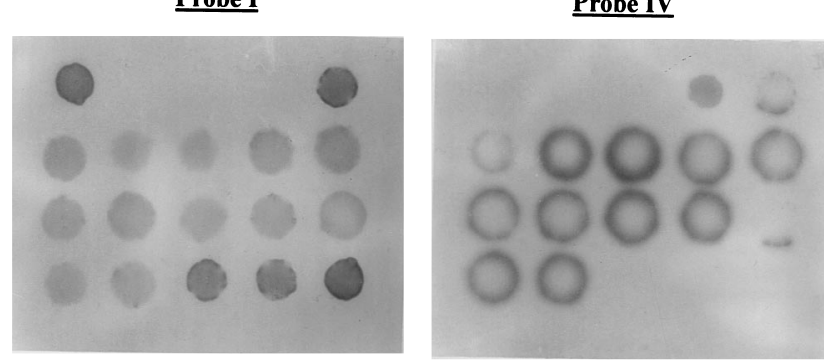

FIG. 4. Lysis zone (plaque) hybridization of $12 \mathrm{~F}^{+}$RNA coliphage isolates from chicken feces by oligoprobes I and IV. The top row contains five positive control coliphages (MS2, GA, Q $\beta$, FI, and ID2). The bottom row contains three mixtures of positive control prototype $\mathrm{F}^{+}$RNA coliphages (MS2+GA, $\mathrm{MS} 2+\mathrm{Q} \beta$, and $\mathrm{MS} 2+\mathrm{FI})$.

ologous groups occurred (Fig. 3). Environmental isolate W1 was classified into group I because of positive hybridization reactions with both probe I and probe A (Fig. 3B). On the basis of their positive reactions with homologous probes, field isolates were classified into group II for E1, group III for W2, and group IV for P1 and P2. These genotypic groupings are the same as those determined by serotyping.

Phage isolate purification and mixed phage plaques. Initially, phage isolates from field samples were picked from plaques and resuspended without any purification prior to serotyping and genotyping. If isolates gave an ambiguous result (cross-reactions with two or more antisera or probes) by either serotyping or genotyping, these initial isolates were purified and tested again. Figure 4 presents the results for 12 initial isolates from chicken feces hybridized with probes I and IV. It is interesting that all 12 isolates formed RNA-probe IV hybrids only at the periphery of the circular lysis zones, thereby forming open circles. These same lysis zones also reacted in their interiors to form RNA-probe I hybrids that were solid circles. The prototype $\mathrm{F}^{+}$RNA coliphage ID2, which is considered serologically intermediate among the four serogroups (12), also reacted with probe IV at the perimeter of the ID2 lysis zone and with probe $I$ in the interior of the lysis zone. Therefore, we speculated that the 12 phage isolates from chicken feces may be either ID2-like phages or mixtures of group I and group IV phages. Indeed, upon further testing after purification (group I phages were isolated and purified by using antigroup IV sera to suppress group IV phages), they were confirmed to be a mixed population of group I and group IV $\mathrm{F}^{+}$ RNA coliphages. Figure 4 shows that when dual mixtures of prototype group I phage MS2 and the prototypes of the other groups were tested for their reactivities with the group I probe and the probes of their actual groups (GA, probe II; Q $\beta$, probe III; and FI, probe IV), they reacted only with probe I. It is notable that a mixture of MS2 and FI was not detected by probe IV as expected (Fig. 4). We suspected that one phage in a mixed population may not be equal in quantity to the other phage because of a difference in growth rate or yield. If the growth rate or yield of MS2 is greater than that of FI, then MS2 predominates in all areas of a circular lysis zone. To confirm this hypothesis, mixtures containing different ratios of group I (MS2) and group IV (FI and SP) phages were tested. We found that at MS2-to-FI ratios of 1:9, 1:99, and 1:999, both phages were clearly detected by both probes I and IV and that MS2 and SP at ratios of 1:99 and 1:999 also were detected by both probes (data not shown). Mixtures of MS2 and SP reacted with probe IV in the interior of the plaques, but mixtures of MS2 and FI reacted with probe IV at the perimeter of the plaques. On the basis of these observations and the hybridization reactions after differential selection of group I and group IV phages by serum neutralization reactions, it seems that the 12 isolates listed in Fig. 4 were mixtures of group I and group IV phages that reacted like mixtures of MS2 and FI phages at ratios of $1: 9$ to $1: 999$.

Serotyping of $\mathbf{2 0 3}$ field isolates. Four types of samples (sewage, oysters, surface waters, and feces) were processed for the isolation of $\mathrm{F}^{+}$RNA coliphages, yielding a total of 203 isolates (Table 2). These coliphage isolates were serotyped by spot neutralization tests and classified into a serogroup if they were

TABLE 2. Classification of $203 \mathrm{~F}^{+}$RNA coliphages from environmental samples by serotyping and genotyping

\begin{tabular}{|c|c|c|c|c|c|c|c|c|c|c|c|c|c|c|c|}
\hline \multirow{2}{*}{ Source } & \multirow{2}{*}{$\begin{array}{c}\text { Total } \\
\text { no. of } \\
\text { isolates }\end{array}$} & \multicolumn{6}{|c|}{$\begin{array}{l}\text { No. of isolates neutralized by antiserum } \\
\text { or antisera against: }\end{array}$} & \multicolumn{5}{|c|}{$\begin{array}{l}\text { No. of isolates hybridized by } \\
\text { oligoprobe of group: }\end{array}$} & \multicolumn{3}{|c|}{$\begin{array}{l}\text { No. of isolates hybridized } \\
\text { by oligoprobe of group: }\end{array}$} \\
\hline & & MS2 & GA & $\mathrm{Q} \beta$ & $\begin{array}{l}\text { SP and } \\
\text { FI }\end{array}$ & $\begin{array}{l}\mathrm{GA} / \\
\mathrm{MS}^{a}\end{array}$ & Unknown & I & II & III & IV & Unknown & A & B & Unknown ${ }^{b}$ \\
\hline Raw sewage ${ }^{c}$ & 10 & 0 & 8 & 0 & 0 & 2 & 0 & 0 & 7 & 0 & 0 & 3 & 10 & 0 & 0 \\
\hline $\begin{array}{l}\text { Secondary } \\
\text { effluent }^{c}\end{array}$ & 12 & 0 & 8 & 0 & 0 & 4 & 0 & 0 & 10 & 0 & 0 & 2 & 12 & 0 & 0 \\
\hline Oysters $^{c}$ & 32 & 0 & 24 & 1 & 0 & 7 & 0 & 0 & 30 & 1 & 0 & 1 & 31 & 1 & 0 \\
\hline Surface water ${ }^{d}$ & 58 & 7 & 22 & 2 & 2 & 24 & 1 & 7 & 45 & 3 & 2 & 1 & 53 & 5 & 0 \\
\hline \multicolumn{16}{|l|}{ Feces } \\
\hline Piglet $^{e}$ & 26 & 0 & 14 & 0 & 12 & 0 & 0 & 0 & 14 & 0 & 12 & 0 & 14 & 12 & 0 \\
\hline $\mathrm{Pig}^{e}$ & 3 & 0 & 3 & 0 & 0 & 0 & 0 & 0 & 3 & 0 & 0 & 0 & 3 & 0 & 0 \\
\hline Chicken ${ }^{f}$ & 62 & 30 & 0 & 0 & 32 & & 0 & 30 & 0 & 0 & 32 & 0 & 30 & 32 & 0 \\
\hline Total & 203 & 37 & 79 & 3 & 46 & 37 & 1 & 37 & 109 & 4 & 46 & 7 & 153 & 50 & 0 \\
\hline
\end{tabular}

${ }^{a}$ Isolates were neutralized completely by anti-GA serum and also neutralized significantly by anti-MS2 serum (by a spot neutralization test the diameter of spots with anti-MS2 serum was $20 \%$ of the diameter of spots from plates without antiserum).

${ }^{b}$ No neutralization or hybridization.

${ }^{c}$ From Calico Creek, N.C.

${ }^{d}$ From Calico Creek, N.C., and New Jersey coastal waters.

${ }^{e}$ From a swine lagoon, Clinton, N.C.

${ }^{f}$ From the 1993 North Carolina State Fair; from chickens from throughout the state. 
TABLE 3. Summary classification of 203 coliphage isolates by serotyping and genotyping

\begin{tabular}{|c|c|c|c|c|c|c|c|}
\hline \multirow{2}{*}{ Phage typing performed with: } & \multicolumn{4}{|c|}{ No. of isolates of coliphage type: } & \multirow{2}{*}{$\begin{array}{l}\text { No. of isolates } \\
\text { of unknown } \\
\text { type }{ }^{a}\end{array}$} & \multirow{2}{*}{$\begin{array}{l}\text { Total no. of } \\
\text { isolates } \\
\text { identified }\end{array}$} & \multirow{2}{*}{$\begin{array}{l}\text { Total \% of isolates classified } \\
\text { (no. classified/total) }\end{array}$} \\
\hline & I & II & III & IV & & & \\
\hline Antisera & 37 & $116^{b}$ & 3 & 46 & 1 & 202 & $99.5(202 / 203)$ \\
\hline Probes I to IV & 37 & 109 & 4 & 46 & 7 & 196 & $96.6(196 / 203)$ \\
\hline Probes $\mathrm{A}$ and $\mathrm{B}$ & 37 & 116 & 4 & 46 & 0 & 203 & $100(203 / 203)$ \\
\hline
\end{tabular}

\footnotetext{
${ }^{a}$ Isolates were not neutralized by antisera or hybridized by probes.

${ }^{b}$ Total identified isolates of group II were calculated by combining isolates neutralized by anti-GA serum with those neutralized by anti-GA serum and anti-MS2
} serum.

neutralized by antiserum of only one group. When isolates could be neutralized by antisera of two or more different groups, they were further purified three times and then spot neutralization tested again. Isolates were considered unclassified if they were not neutralized by any of the five antisera. As shown in Table 2, all isolates but one from surface water reacted with antisera and could be classified. The majority of the field isolates from raw and treated sewage, oysters, surface waters, and porcine feces were unequivocally identified as group II phages. However, the phage isolates from chicken feces belonged to either group I or group IV. A total of 37 isolates from raw sewage, secondary effluent, oysters, and surface waters gave ambiguous results because they were neutralized completely by anti-GA (group II) serum and neutralized partially by anti-MS2 (group I) serum.

Genotyping of 203 field isolates. Six phage oligoprobes, one each for group I, group II, group III, and group IV phages, A for both group I and group II phages, and B for both group III and group IV phages, were used in hybridization tests to classify the field isolates that had been serologically tested. For example, a group I phage like MS2 would hybridize only with probes I and A, while a group IV phage like FI would hybridize only with probes IV and B. As shown in Table 2, most isolates reacted with an individual group probe (I, II, III, or IV) and either with probe A (groups I and II) or probe B (groups III and IV), and the hybridization results were generally consistent with the serological results. As with the results of serotyping, the majority of the isolates from raw sewage, secondary effluent, and porcine feces were classified as group II phages by their hybridization reactions. The $\mathrm{F}^{+}$RNA coliphages from chicken feces were classified definitively by genotyping into groups I and IV, and this is also quite consistent with the results of serotyping.

Comparison of genotyping and serotyping for 203 field isolates. While serotyping and genotyping gave generally consistent results for most of the $203 \mathrm{~F}^{+}$RNA coliphage isolates, a few isolates could not be conclusively typed by either or both methods. Of the 10 isolates from raw sewage, all were neutralized by group II antisera, but two of them also were partially neutralized by group I serum. By hybridization, all 10 reacted with probe A and not with probe B (Table 2). When tested with probes I to IV, 7 of these 10 isolates were classified as group II, but 3 were not reactive by hybridization with any of these probes. The majority of isolates from secondary effluent and oysters were serotyped and genotyped as group II. Two of 12 isolates from secondary effluent and 1 of 31 isolates from oysters were not classifiable by using probes I through IV, while 4 of the 12 secondary effluent isolates and 7 of the 31 oyster isolates reacted with both group I and group II antisera. For 58 isolates from surface waters, 1 was serotyped as group II but was untypeable by hybridization and another that was genotyped as group III did not react with any of the antisera.

Table 3 shows that overall group identification of $\mathrm{F}^{+}$RNA coliphages was $99.5 \%$ by serotyping, $96.6 \%$ by genotyping with probes I through IV, and $100 \%$ by genotyping with probes $\mathrm{A}$ and B. The total of group II phages identified by serotyping (116) was higher than that identified by genotyping using probes I through IV (109). The number of isolates untypeable by serotyping (1) was smaller than that untypeable by hybridization with probes I through IV (7). However, there was no significant difference between genotyping and serotyping for $\mathrm{F}^{+}$RNA coliphage grouping $(P<0.05$ [analysis of variance] $)$.

\section{DISCUSSION}

Nucleic acid hybridization techniques have been successfully used to classify a variety of microorganisms, including $E$. coli strains $(8,29,33)$, rotaviruses $(20,30)$, hepatitis $C$ virus $(32)$, and herpes simplex virus (25). These hybridization techniques have many advantages over neutralization by antisera for identification and differentiation of serotypes of microorganisms. However, cross-reactions with unrelated phages or other organisms may occur when oligoprobes with common sequences are used for hybridization reactions (1). In developing an oligoprobe hybridization method to group $\mathrm{F}^{+}$RNA coliphages, a number of key technical issues had to be successfully addressed. These were as follows: (i) the development of simple and efficient methods to isolate target phages for subsequent identification, (ii) the selection of specific oligoprobes that provide correct identification, and (iii) the development of optimized hybridization reagents and reaction conditions, including the choice of blotting membranes and the identification of an appropriate denaturant and appropriate denaturing conditions for transferred phages and the optimal hybridization conditions to achieve specificity and sensitivity.

Efficient isolation of $\mathrm{F}^{+}$RNA coliphages was achieved by using a specific host strain (S. typhimurium WG49) and by screening field isolates by an RNase test to identify those that contained RNA. The $S$. typhimurium WG49 host strain is reported to yield a high proportion of $\mathrm{F}^{+}$RNA coliphages, and in this study, more than $90 \%$ of the phage isolates were identified as $\mathrm{F}^{+}$RNA coliphages.

Five commercial nylon membranes were tested in this study to determine which are efficient for transfer of $\mathrm{F}^{+}$RNA coliphages from zones of lysis on plates. The results of comparative studies showed that membranes differed in sensitivity and specificity for $\mathrm{F}^{+}$RNA coliphage plaque (lysis zone) hybridization with each probe. Three of the five membranes (GeneScreen, nylon membranes from Boehringer Mannheim, and Biodyne) had high efficiency for phage transfer, while the other two (Biotrans and Zeta-probe) produced nonspecific hybridization.

Typically, RNA is denatured by formaldehyde with heating at $68^{\circ} \mathrm{C}$ for $15 \mathrm{~min}$ prior to dot or slot blotting (23). In this study, a blotting buffer was adapted to the denaturation of phage RNA directly on membranes. With blotting buffer, 
phages transferred from lysis zones on host lawns exhibited high sensitivity in hybridization reactions, even after being transferred to nylon membrane filters three times in succession. Such application of blotting buffer for RNA denaturation in plaque (lysis zone) hybridization assays has not been previously reported.

Hybridization conditions were optimized to provide probe specificity and sensitivity by using a high concentration ( 5 $\mathrm{pmol} / \mathrm{ml}$ ) of probes, a hybridization temperature of $45^{\circ} \mathrm{C}$, and a concentrated washing solution $(6 \times$ SSC with $0.1 \%$ SDS).

Field isolates of $\mathrm{F}^{+}$RNA coliphages are normally purified before they can be serotyped by spot neutralization tests (11, 16). However, in this study, phage isolates as lysis zones on agar plates were not purified before being serotyped and genotyped, because such purification is costly and laborious. It was found that the vast majority of $\mathrm{F}^{+}$RNA coliphage isolates (about $87 \%$ ) could be correctly and unambiguously identified without prior purification. The remaining isolates still required purification because they were neutralized or hybridized by two or more antisera or probes, respectively. Attempting classification of field isolates without purification took much less time than the conventional method of purification before serotyping.

If initial phage isolates are a mixture containing more than one group, they could be unclassifiable by neutralization spot tests, because the heterologous group still can proliferate to lyse host cells and form a clear circular zone on the agar medium host cell lawn. However, the potentially ambiguous reactions of phage mixtures in serum neutralization spot tests are avoided by hybridization tests because reactions with multiple probes are readily recognized as indicative of a mixed population. Twelve initial isolates from chicken feces that hybridized with probes I, A, IV, and B were subsequently confirmed through plaque assay neutralization testing to contain a mixed population of group I and group IV phages. One antiserum of the two phages in the mixture was added to the top agar of the plaque assay medium to suppress the homologous group of phages and allow the growth of the heterologous group of phages. When plaques from plates with each antiserum were picked, spotted, and oligoprobed, the identification of each group in the initially unpurified isolate mixture could be serologically confirmed.

It is noteworthy that 17 isolates from piglet and pig feces were classified as group II phages, but this group was not found in any other animal feces. This observation, which is consistent with other reports $(12,27)$, suggests that group classification will not always distinguish between human and porcine fecal contamination. Because the dietary and living conditions of pigs have historically involved exposure to human fecal wastes, this may account for the detection of group II phages in pig feces. Once introduced into the pig population, these phages may persist because the gastrointestinal physiology and flora of pigs are relatively similar to those of humans.

In general, most $\mathrm{F}^{+}$RNA coliphage isolates from samples impacted by human sewage were group II and those from nonhuman (chicken) sources were groups I and IV. In previous studies group III phages were found only in human feces (27), and all isolates from animal feces were grouped as serogroups I and IV, with the exception of porcine feces $(16,27)$. In the present study and in previous studies, group II phages predominated in human feces and wastewaters. Hence, group I and group IV phages found in water and food samples indicate primarily animal fecal contamination, and groups II and III suggest primarily human sources.

The positive correlation previously found between concentrations of $\mathrm{F}^{+}$RNA coliphages and enteric viruses in surface water suggests that the presence of enteric viruses can be predicted by the presence of $\mathrm{F}^{+}$RNA coliphages (18). Grouping $\mathrm{F}^{+}$RNA coliphages from environmental samples would help to determine if the sources of contamination were human or animal and perhaps further strengthen the associations with human enteric viruses. In this study, the presence of group II $\mathrm{F}^{+}$RNA coliphages in raw sewage, secondary effluent, surface waters, and oysters indicated that those samples were impacted by human waste sources. One isolate from oysters and two isolates from surface waters were serotyped as group III phages, also indicating human fecal sources. Hence, on the basis of typing results $\mathrm{F}^{+}$RNA coliphages appear to be promising indicators for monitoring and distinguishing between human and animal fecal contamination of water and food.

The overall percentage of $\mathrm{F}^{+}$RNA coliphage classification of 203 field isolates by serotyping $(99.5 \%)$ was slightly greater than that by hybridization with probes I through IV (96.6\%), but there was no significant difference $(P<0.05)$ between these two methods. Of 37 isolates that were neutralized weakly by anti-MS2 (group I) serum and strongly by anti-GA (group II) serum, 30 were genotyped as group II and 7 could not be genotyped. The morphology of these seven isolates was unique in that plaques on WG49 lawns were not identical after five cycles of purification.

Several $\mathrm{F}^{+}$RNA coliphages have been reported as serological intermediates between groups I and II and between groups III and IV $(9,10)$, and some of these, such as phage JP34, have been serotyped as group I but genotyped as group II $(3,21)$. Moreover, a spontaneous mutant from a group II phage (GA), on which a G-to-A transition occurred at the coat protein gene, developed resistance to anti-GA serum and sensitivity to antiMS2 serum (14). These strains have contributed to the ambiguous results observed for serotyping, and such strains may have been detected in the present study. However, genotyping by hybridization with oligoprobes would seem to be a useful tool for resolving the problematic serological differences between the group intermediates because specific targets of nucleotide sequence in $\mathrm{F}^{+}$RNA coliphages can be detected. The overall comparability of genotype results to serotype results in this study demonstrates that genotyping is an effective and technically feasible method for grouping $\mathrm{F}^{+}$RNA coliphages.

\section{ACKNOWLEDGMENTS}

This study is based on work supported by the Cooperative State Research Service, U.S. Department of Agriculture, under Agreement no. 92-34214-7319 and 93-37201-9193. J.V.D. and M.J.B. acknowledge the Dutch Foundation STW for financial support under grant no. LCH88.1580.

We thank Hyenmi Chung and Gregory Lovelace for field sample collection and analyses.

\section{ADDENDUM IN PROOF}

A method to assay and genotype $\mathrm{F}^{+}$RNA coliphages by using radioactively labeled probes, some of which have the same nucleotide sequences as those described here, has recently been described (4a)

\section{REFERENCES}

1. Ackermann, H. W., M. S. DuBow, A. W. Jarvis, L. A. Jones, V. N. Krylov, J. Maniloff, J. Rocourt, and R. S. Safferman. 1992. The species concept and its application to tailed phages. Arch. Virol. 124:69-82.

2. Adams, M. H. 1959. Bacteriophages. Wiley Interscience, New York.

3. Adhin, M. R., A. Hirashima, and J. Van Duin. 1989. Nucleotide sequence from the ssRNA bacteriophage JP34 resolves the discrepancy between serological and biophysical classification. Virology 170:238-242.

4. Battigelli, D. A. 1992. The inactivation of hepatitis A virus and other model viruses by chlorine dioxide and UV radiation. M.S. thesis. University of 
North Carolina, Chapel Hill.

4a.Beekwilder, J., R. Nieuwenhuizen, A. H. Havelaar, and J. van Duin. An oligonucleotide hybridization assay for the identification and enumeration of F-specific RNA phages in surface water. J. Appl. Bacteriol., in press.

5. Benton, W. D., and R. W. Davis. 1977. Screening $\lambda$ gt recombinant clones by hybridization to single plaques in situ. Science 196:180.

6. Berman, D., R. Sullivan, and C. J. Hurst. 1992. Effect of the method of preparing monochloramine upon inactivation of MS2 coliphage, E. coli, and Klebsiella pneumoniae. Can. J. Microbiol. 38:28-33.

6a.Boehringer Mannheim. 1995. The user's guide for filter hybridization. Boehringer Mannheim, Indianapolis, Ind.

7. Chung, H. 1993. F-specific coliphages and their serogroups, and Bacteroides fragilis phages as indicators of estuarine water and shellfish quality. Ph.D. thesis. University of North Carolina, Chapel Hill.

8. Feng, P. 1993. Identification of E. coli serotype O157:H7 by DNA probe specific for an allele of uid A gene. Mol. Cell. Probes 7:151-154.

9. Furuse, K., A. Ando, and I. Watanabe. 1975. Isolation and grouping of RNA phages. VII. A survey in Peru, Bolivia, Mexico, Kuwait, France, Australia, and the United States of America. J. Keio Med. Soc. 52:355-361.

10. Furuse, K., T. Aoi, T. Shiba, T. Miyake, and I. Watanabe. 1973. Isolation and grouping of RNA phages. IV. A survey in Japan. J. Keio Med. Soc. 50:363376.

11. Furuse, K., T. Sakurai, A. Hirashima, M. Katsuki, A. Ando, and I. Watanabe. 1978. Distribution of RNA coliphages in South and East Asia. Appl. Environ. Microbiol. 35:995-1002.

12. Furuse, K. 1987. Distribution of coliphages in the environment: general considerations, p. 87-123. In S. M. Goyal, C. P. Gerba, and G. Bitton (ed.), Phage ecology. Wiley-Interscience, New York.

13. Gerba, C. P. 1987. Phage as indicators of fecal pollution, p. 197-210. In S. M. Goyal, C. P. Gerba, and G. Bitton (ed.), Phage ecology. Wiley-Interscience, New York.

14. Harigai, H., K. Furuse, Y. Inokuchi, and A. Hirashima. 1986. Characterization of an intergroup serological mutant from group II RNA phage GA. Microbiol. Immunol. 30:1247-1257.

15. Havelaar, A. H. 1987. Bacteriophages as model organisms in water treatment. Microbiol. Sci. 4:362-364.

16. Havelaar, A. H., W. M. Pot-Hogeboom, K. Furuse, R. Pot, and M. P. Hormann. 1990. F-specific RNA bacteriophages and sensitive host strains in faeces and wastewater of human and animal origin. J. Appl. Bacteriol. 69:30-37.

17. Havelaar, A. H., W. M. Pot-Hogeboom, and R. Pot. 1984. F-specific RNA bacteriophages in sewage: methodology and occurrence. Water Sci. Technol. 17:645-655.

18. Havelaar, A. H., M. van Olphen, and Y. C. Drost. 1993. F-specific RNA bacteriophages are adequate model organisms for enteric viruses in fresh water. Appl. Environ. Microbiol. 59:2956-2962.

19. Hedberg, C. W., and M. T. Osterholm. 1993. Outbreaks of food-borne and waterborne viral gastroenteritis. Clin. Microbiol. Rev. 6:199-210.
20. Hussein, H. A., A. V. Parwani, B. I. Rosen, A. Lucchelli, and L. J. Saif. 1993. Detection of rotavirus serotypes G1, G2, G3, and G11 in feces of diarrheic calves by using polymerase chain reaction-derived cDNA probes. J. Clin. Microbiol. 31:2491-2496.

21. Inokuchi, Y., A. Hirashima, and I. Watanabe. 1982. Comparison of the nucleotide sequences at the 3 '-terminal region of RNAs from RNA coliphages. J. Mol. Biol. 158:711-730.

22. Joklik, W. K. 1992. Structure, components, and classification of viruses, p. 749-782. In W. K. Joklik, H. P. Willett, D. B. Amos, and C. M. Wiffert (ed.), Zinsser microbiology. Appleton \& Lange, San Mateo, Calif.

23. Kafatos, F. C., C. W. Jones, and A. Efstratiadis. 1979. Determination of nucleic acid sequence homologies and relative concentrations by a dot hybridization procedure. Nucleic Acids Res. 7:1541.

24. Le-Guyader, F., V. Apaire-Marchais, J. Brillet, and S. Billaudel. 1993. Use of genomic probes to detect hepatitis A virus and enterovirus RNAs in wild shellfish and relationship of viral contamination to bacterial contamination. Appl. Environ. Microbiol. 59:3963-3968.

25. Matsumoto, T., O. Yamada, A. Itagaki, S. Ishida, T. Kamahora, and T. Kurimura. 1992. Rapid DNA diagnosis of herpes simplex virus serotypes. J. Virol. Methods 40:119-125.

26. Moore, A. C., B. L. Herwaldt, G. F. Craun, R. L. Calderon, A. K. Highsmith, and D. D. Juranek. 1993. Surveillance for waterborne disease outbreaksUnited States, 1991-1992. Morbid. Mortal. Weekly Rep. CDC Surveill. Summ. 42:1-22.

27. Osawa, S., K. Furuse, and I. Watanabe. 1981. Distribution of ribonucleic acid coliphages in animals. Appl. Environ. Microbiol. 41:164-168.

28. Sambrook, J., E. F. Fritsch, and T. Maniatis. 1989. Molecular cloning: a laboratory manual, 2nd ed., p. 1.90-1.104. Cold Spring Harbor Laboratory Press, Cold Spring Harbor, N.Y.

29. Scotland, S. M., G. A. Willshaw, H. R. Smith, B. Said, N. Stokes, and B. Rowe. 1993. Virulence properties of $E$. coli strains belonging to serogroups O26, O55, O111, and O128 isolated in the United Kingdom in 1991 from patients with diarrhea. Epidemiol. Infect. 111:429-438.

30. Sethabutr, O., S. Hanchalay, U. Lexomboon, R. F. Bishop, I. H. Holmes, and P. Echeverria. 1992. Typing of human group A rotavirus with alkaline phosphatase-labeled oligonucleotide probes. J. Med. Virol. 37:192-196.

31. Sobsey, M. D., K. J. Schwab, and T. R. Handzel. 1990. A simple membrane filter method to concentrate and enumerate male-specific RNA coliphages. J. Am. Water Works Assoc. 82(9):52-59.

32. Stuyver, L., R. Rossau, A. Wyseur, M. Duhamel, and B. Vanderbroght. 1993 Typing of hepatitis $\mathrm{C}$ virus isolates and characterization of new subtypes using a line probe assay. J. Gen. Virol. 74:1093-1102.

33. Thomas, A., H. R. Smith, and B. Rowe. 1993. Use of digoxigenin-labeled oligonucleotide DNA probes for VT2 and VT2 human variant genes to differentiate Vero cytotoxin-producing E. coli strains of serogroup O157. J. Clin. Microbiol. 31:1700-1703.

34. Watanabe, I., T. Miyake, T. Sakurai, T. Shiba, and T. Ohno. 1967. Isolation and grouping of RNA phages. Proc. Jpn. Acad. 43:204-209. 